\title{
Grief and Mourning during the COVID-19 Pandemic in Portugal
}

\section{Angústia e Luto durante a Pandemia de COVID-19 em Portugal}

\author{
Ana AGUIAR $\triangle^{1}$, Marta PINTO2 ${ }^{2}$, Raquel DUARTE ${ }^{1,3,4}$ \\ Acta Med Port 2020 Sep;33(9):543-545 - https://doi.org/10.20344/amp.14345
}

Keywords: Bereavement; COVID-19; Grief; Mental Health

Palavras-chave: COVID-19; Luto; Pesar; Saúde Mental

The current epidemiological situation caused by the coronavirus disease 2019 (COVID-19) has forced us to adjust our lifestyle and most of our behaviors as no other recent health circumstance has. In addition to the social, emotional, economic and financial impact, the measures to control the disease have also affected the way we, both as a society and as individuals, cope with death.

We intend to discuss how the public health strategies implemented to mitigate the spread and morbidity of COVID-19 have changed traditional burial rituals as well as the related grief and bereavement processes. Moreover, we aim to address potential policy changes.

The COVID-19 pandemic and the physical distancing measures that many countries have enforced have caused disruptions to daily routines as well as the usual lived and subjective experience of grief and bereavement. In Portugal, some guidelines were published at the beginning of the pandemic regarding post-mortem care, autopsy and mortuary care, as determined by the Direção-Geral da Saúde (DGS). ${ }^{1}$ The aim of this guideline was to define the procedures for the after-death care of individuals with suspected or confirmed infection by severe acute respiratory syndrome coronavirus 2 (SARS-CoV-2) in order to ultimately protect the health of the community.

Even before death, any terminally ill patients hospitalized were in isolation. Accordingly, the presence of family members and loved ones during such crucial moments became impossible. However, the impact of these circumstances among both patients and their families is yet to be fully understood. Besides facing such arduous conditions over the last days of life, COVID-19 protection measures also created a challenging post-death scenario, since funerals and burials were postponed or held remotely, with the presence of a maximum of 10 people..$^{2,3}$

Therefore, in a situation of sudden death or death during hospitalization, and in accordance with the aforementioned guideline, when an individual dies with suspected or confirmed infection by SARS-CoV-2, the corpse is removed and never seen again by family members. The identification of the body is carried out entirely remotely, often with a funeral agency intermediate, through digital photographs of the face. The corpse is kept in a waterproof bag, naked, without the attire usually chosen by the family, and in a closed coffin that remains shut during the funeral.

The constraints experienced in the farewell moment, of cultural and religious nature, may disrupt the family and the mourning process. During these unprecedented times, individuals who experience the sudden death of a family member or friend, already miss the anticipatory grief (normal mourning experienced when death is expected $)^{4}$ and are now also prevented from a proper farewell. To make matters worse, they are not allowed to have physical or current spiritual support or to receive the affection of family members and friends.

As such, some changes are recommended below to ensure that the COVID-19 protective measures are more comprehensive and humanistic. This would allow, on one hand, to protect the community during the pandemic, but on the other hand, the possibility to carry out proper farewell rituals associated with the loss of a loved one. This may help families and friends to cope with grief and mourning during the pandemic regardless of the cause of death.

\section{Mental care support}

Offering the contact information of highly accessible psychological support services to individuals experiencing the loss of a loved one should become a priority at both the hospital and/or the Institute of Forensic Medicine. We should work collectively towards improving access to psychological interventions, including face-to-face support, when possible or, remote psychological support through mobile phones or an online format. Special attention must be paid to the fact that grief may follow a different course after sudden and violent losses compared with losses from natural deaths. The nature and circumstances of the former make it more difficult for the bereaved to grasp the reality

1. EPIUnit - Instituto de Saúde Pública. Universidade do Porto. Porto. Portugal.

2. Faculdade de Psicologia e Ciências da Educação. Universidade do Porto. Porto. Portugal.

3. Departamento de Ciências de Saúde Pública, Ciências Forenses e Educação Médica. Universidade do Porto. Porto. Portugal.

4. Serviço de Pneumologia. Centro Hospitalar de Vila Nova de Gaia/Espinho. Vila Nova de Gaia. Portugal.

$\triangle$ Autor correspondente: Ana Aguiar. ana.aguiar@ispup.up.pt

Recebido: 15 de junho de 2020 - Aceite: 25 de junho de 2020 | Copyright $\odot$ Ordem dos Médicos 2020 
of the loss, and grief reactions may intensify. ${ }^{5} \mathrm{~A}$ structured approach to bereavement care that is integrated has great potential to reduce the stressors of family members faced with the sudden and unexpected death of a loved one. ${ }^{6} \mathrm{~A}$ trained and board-certified professional should be considered.

\section{Adapt the procedures of body identification and prepa- ration for burial}

An unexpected death is a marked feature of a coronavirus-related death, and this bereavement characteristic may lead to maladaptive coping and difficulty in adjusting to a new reality. Recognizing the uniqueness of each individual's death (due to COVID-19 or do not), adapting the procedures of body identification - by allowing the recognition of the body in person and not through photos (often sent by the funeral agencies because they make the bridge between families and medical services), with the use of the appropriate protective equipment and for a short period of time, at the hospital or at the Institute of Forensic Medicine, will help families face the loss and grief in a more humanely manner, because they will be able to see the relative for one last time.

\section{Allow for spiritual support, and for the support of family and friends}

Spiritual beliefs may provide an existential framework in which grief is more readily resolved. ${ }^{7}$ Most spiritual beliefs, regardless of being associated or not with religious practice, contain tenets about the course of human life and existence beyond it. Bereaved survivors should be informed about the psychological impact of a traumatic loss and the process of grieving, and supportive resources for families should be available. In particular, written material for followup contacts, the availability of hospital and/or communitybased grief support systems, mental health services as well as spiritual and religious care should be considered. Even though they may not provide definitive answers to questions and issues of spiritual distress, they may help individuals in mental distress to identify and draw upon their sources of spiritual strength regardless of their religion or beliefs.

\section{REFERENCES}

1. Direção-Geral da Saúde. Infeção por SARS-CoV-2 (COVID-19) Cuidados post mortem, autópsia e casas mortuárias. 2020. [accessed 2020 June 4]. Available from: https://www.dgs.pt/directrizes-da-dgs/ normas-e-circulares-normativas/norma-n-0022020-de-16032020-pdf. aspx.

2. Observador.pt. Velórios sem padre e funerais limitados a dez pessoas. Como a Covid-19 está a mudar as cerimónias fúnebres em Portugal. 2020. [accessed 2020 June 23]. Available from: https://observador.pt/ especiais/velorios-sem-padre-e-funerais-limitados-a-dez-pessoascomo-a-covid-19-esta-a-mudar-as-cerimonias-funebres-em-portugal/.

3. Decreto $n .{ }^{\circ} 2-B / 2020$. Diário da República I Série, $n^{\circ} 66$ (2020/04/02). p. 31(2)-(20).

4. Shore J, Gelber M, Koch L, Sower E. Anticipatory grief: an evidencebased approach. J Hosp Palliat Nurs. 2016;18:15-19.

5. Kristensen P, Weisæth L, Heir T. Bereavement and mental health after sudden and violent losses: a review. Psychiatry. 2012;75:76-97.

\section{Allow for the presence of family and friends}

Until recently, the restrictions experienced by those who lost a family member, when it comes to the number of people allowed at funerals, was quite limited. Only since the $4^{\text {th }}$ May 2020, and according to the reopening calendar approved by the Council of Ministers (30 ${ }^{\text {th }}$ April 2020), family members were allowed in funerals although, as the Prime Minister mentioned "the rule that it is incumbent on mayors, as local civil protection authorities, to define the maximum limit regarding the number of people who can attend a funeral" remains. . $^{8,9}$

Even though the state of emergency has been lifted in Portugal, just like in other countries, and that there is still much to know about SARS-CoV-2 and COVID-19, outbreaks continue to occur and as we can see from the most recent data regarding Lisbon Metropolitan Area, where 19 parishes in five municipalities of the mentioned Metropolitan Area, remain in a state of calamity due to the increase number in new cases of COVID-19.

Therefore, more restrictive measures can again be implemented like we've seen recently in the Lisbon Metropolitan Area. This could represent again a setback in allowing family members to attend funerals.

In this sense, it is important to point out that there is no known risk of infection by being in the same room with the corpse of someone who has died due to COVID-19 at a funeral. ${ }^{10}$ Although transmission may occur between individuals at the funeral, this can be avoided with the same rules applied to other events where the presence of more people is allowed, namely physical distancing, frequent hand washing, respiratory etiquette and the use of a face mask.

It is necessary to consider changes to the procedures and rules, and tailor strategies that can facilitate the functional adjustment to loss, while also promoting mental health and wellbeing during the COVID-19 pandemic.

\section{CONFLICT OF INTEREST}

All authors declare that they have no conflict of interest.

\section{FUNDING SOURCES}

None stated.

6. Wilson W, Grande C, Hoyt D. Trauma critical care. Taylor and Francis group. 2007. [accessed 2020 June6].Available from: https://books.google. pt/books?id=3H3AIEtvc8YC\&pg=PA1148\&lpg=PA1148\&dq=Allow+for +spiritual+support+and+the+support+of+family+and+friends+grief\&so urce=bl\&ots=p6S4BF_dTa\&sig=ACfU3U1X_dTyAhlsW-c9E4m0pf589QADA\&hl=pt-PT\&sa=X\&ved $=2$ ahUKEwj54 bG9 vpAhUh8AKHfBIAvAQ6AEwEHoECAQQAQ\#v=onepage\&q=Allow $\% 20$ for $\% 20$ spiritual\%20support $\% 20$ and $\% 20$ the $\% 20$ support $\% 20$ of $\% 20$ family $\% 20$ and $\% 20$ friends $\% 20$ grief\&f $=$ false.

7. Walsh K, King M, Jones L, Tookman A, Blizard R. Spiritual beliefs may affect outcome of bereavement: prospective study. BMJ. 2002;324(7353):1551.

8. Portugal.gov.pt. Plano de Desconfinamento. Resolução do Conselho de Ministros. 2020. [accessed 2020 June 23]. Available from: https:// www.portugal.gov.pt/pt/gc22/comunicacao/documento?i=plano-dedesconfinamento. 
9. Visão.sapo.pt. Covid-19: Presença de familiares em funerais volta a ser permitida a partir de segunda-feira. 2020. [accessed 2020 June 23]. Available from: https://visao.sapo.pt/atualidade/politica/2020-04-30covid-19-presenca-de-familiares-em-funerais-volta-a-ser-permitida-a- partir-de-segunda-feira/.

10. Centers for Disease Control and Prevention. COVID-19 and Funerals. 2020. [accessed 2020 June 6]. Available from: https://www.cdc.gov/ coronavirus/2019-ncov/faq.html\#COVID-19-and-Funerals. 